\title{
Analysis of the Formation of Terms Related to Covid-19 as Lecture Material Diction in General Bahasa Indonesia Courses
}

\author{
Siti Hamidah ${ }^{1}$,* Welsi Damayanti ${ }^{1}$ \\ ${ }^{1}$ General Education Indonesia University of Education, Bandung, Indonesia \\ *Corresponding author.Email: sitihamidah@upi.edu welsi_damayanti@upi.edu
}

\begin{abstract}
The Government of Indonesia gave rise to various policies to break the chain of the spread of Covid-19. These policies are socialized to the public through the term. Responding to the terminology phenomenon related to Covid-19 is interesting because there are processes and results of creating language. This is in line with the application of Indonesian general courses at the college level. One of the material relating to the phenomenon of making a term in the Covid-19 pandemic situation is the "Diction" lecture material. This study aims to describe the process of forming the terms related to Covid-19 as an alternative material for lecture material in Indonesian general courses using qualitative descriptive methods. The result of data collection from sources of mass communication that is there are 80 terms used in mass communication media. Based on the analysis of the formation of terms there are 15 terms matching through translation, 21 terms with absorption, 20 terms with a combination of translation and absorption, 10 terms in acronym form, 9 special terms used in government policy from a geospatial perspective, and 5 other terms that appear in the latest rules to replace the terms that already existed in the previous policy. The list of terms related to Covid-19 that has been analysed can be used as an exercise or example in the application of the concept of shaping terms in diction learning so that lecturers and students get a more contextual form of material content.
\end{abstract}

Keywords: term formation; covid-19 terms; general courses; Bahasa Indonesia

\section{INTRODUCTION}

March, 2020 is the beginning for the Indonesian people to have direct contact with all matters concerning the situation, conditions, information and policies related to Covid-19. Covid-19 (Coronavirus Disease 2019) is an infectious disease reported by the World Health Organization (WHO) on December 31, 2019 as an acute pneumonia originating from Wuhan City, Hubei Province, China. After the report, confirmed cases of Corona virus began to appear all over the world so that on March 11, 2020, WHO has established Covid-19 as a pandemic. [1, 2]. Indonesia reported the first case on March 2, 2020. Cases are increasing and spreading rapidly throughout Indonesia. As of July 18, 2020 the Indonesian Ministry of Health reported 84,882 confirmed cases of Covid-19 with 4,016 deaths [3].

In the midst of the Covid-19 pandemic in Indonesia, various government policies emerged to break the chain of the spread of Covid-19. These policies are packaged in linguistic products, i.e. terms. Through these terms, government policies are disseminated to the public. Term is a vocabulary used as a name to summarize the concepts, processes, circumstances, or characteristics that are unique in the fields of science, technology, and art [4-6]. Term that appears starts from naming the case, context and status, action, facility and infrastructure, rules, and other matters related to the Covid-19 phenomenon. Terms that emerged initially were dominated by special terms in the health field, such as antiseptics, PPE (Personal Protection Equipment), chloroquine, medical masks, droplets, thermo guns, pneumonia, respirators, specimens, suspects, rapid tests, swab test, ventilator, and others. The term in the health field became popular in the general public during the Covid-19 pandemic. Not surprisingly, the terms in the health field are considered new terms for public consumption.

Social change will affect the forms of language, one of which is the use of the term. The use of the term is inseparable from social phenomena [7] specifically what happened during the Covid-19 pandemic. This is due to the dynamic nature of language [8]. Responding to the Covid19 phenomenon from the point of view of language becomes interesting because of the process and results of creating language in terms that arise in the Covid-19 pandemic situation. This phenomenon is proof that language is a general ability possessed by every human who utilizes language as a medium of communication, interaction, and expression. Bahasa Indonesia during this pandemic must be able to accommodate a variety of new terms [9]. This is in line with the application of Bahasa Indonesia course especially as general courses at college level. Bahasa Indonesia course as general courses that are required to be given to all students at the college level in Indonesia, as mandated in Law Number 12 of 2012 concerning Higher Education Article 35 paragraph (3). 
Bahasa Indonesia course is also an instrument for developing and honing students' skills in using Bahasa Indonesia as a means of communication, interaction, and expression in both the social and academic fields.

One of the material related to the phenomenon of coined the term in the Covid-19 pandemic situation is the "Diction" lecture material. Diction in Indonesia Dictionary (KBBI) [10] is the right choice of words to express an idea so that the desired goal is obtained by selecting the word. The sub-material of this diction is the formation of words. The main source of this submission is the General Guidelines for the Formation of Terms (PUPI) of the Republic of Indonesia Ministry of Education Number 146/2/2004 [5]. Therefore, this study aims to analyze the process of forming the terms related to Covid-19 and describe them and then serve as an alternative material for lecture diction material in Bahasa Indonesia subject.

Bahasa Indonesia course is a strategic course for the delivery of products and language policies in general issued by the Language Agency of the Ministry of Education and Culture (Kemdikbud). As stated by Gusnayetti [9] the general objective of Bahasa Indonesia course in tertiary education is to maintain awareness of the existence of norms or guidelines for Bahasa Indonesia grammar as a reference material in the use of Bahasa Indonesia that obey the principles. Therefore, scientific material in Bahasa Indonesian course especially regarding language regulations lacks of significant changes. Thus, Bahasa Indonesia lecturers are required to make updates on the presentation of content that delivers scientific material to fit the social context experienced by the students. The update of the presentation of general course content is intended to be increasingly felt by all students of various disciplines in higher education..

\section{METHOD}

This study uses descriptive qualitative research methods. As stated by Raco [11] research data with qualitative methods can be in the form of text, photos, stories, and others except numerical calculations. This research data is included in the form of text. The research data was collected from terms related to Covid-19 which appeared in general and official news in the communication media, including mass media, dictionaries, and web-based internet networks. [12]. Terms related to Covid-19 in official news issued by the Covid-19 Response Acceleration Task Force (covid19.go.id), Ministry of Health (covid19.kemkes.go.id; infeksiemerging.kemkes.go.id), Ministry of Education and Culture (spai.kemdikbud.go.id, ahlibahasa. kemdikbud. go.id), and Ministry of Tourism (pedulicovid.19. kemenparekraf.go.id) as well as from online news from official media, namely kompas.com, republika.co.id, tempo.co, liputan6.com, mediaindonesia.com, tirto.id, tagar.id, and katadata.co.id. The data collected from various online media is carried out as data triangulation in order to represent the object of the intended research. The term data that has been obtained is then analyzed based on categories based on the General Guidelines for Formation of Terms Decree of the Minister of National Education of the Republic of Indonesia (PUPI) Number 146/2/2004 [5] dan Bahasa Indonesian extension series Tata Istilah, Ministry of Education and Culture 2016 [4]. Both of these guidelines are rules that apply to the formation of terms in Indonesian.

\section{RESULTS AND DISCUSSION}

Based on the results of data collection from official legal entities there are 80 terms related to Covid-19. The dominance of English in terms related to Covid-19 proves that Covid-19 is a global pandemic affecting the world. As said by Ashilah that English has a significant role in influencing other languages in the world [13], The results of the analysis of the formation of terms guided by PUPI Decree of the Minister of National Education of the Republic of Indonesia Number 146/2/2004 and Bahasa Indonesian extension series Tata Istilah, Ministry of Education and Culture 2016, there are three types of terminology especially by matching foreign terms related to Covid-19 into Bahasa Indonesia, namely translation, absorption, and a combination of translation and absorption $[4,5,13]$.

There are 15 terms matching them through translation. The fifteen terms consist of: 6 terms translated from English in the form of words into words, namely tracing, screening, survivor, droplet, confirmed, and outbreak; 8 terms translated from phrase form to phrase, namely hazmat mask, herd immunity, new normal, face shield, physical distancing, hand sanitizer, rapid test, and swab test; and 1 term which is translated from the word form into a phrase, namely lockdown to karantina wilayah.

TABLE I. FORMATION OF TERMS THROUGH TRANSLATION

\begin{tabular}{|l|l|l|}
\hline \multicolumn{1}{|c|}{ Indonesian Term } & \multicolumn{1}{c|}{ Foreign Term } & \multicolumn{1}{c|}{ Form } \\
\hline alat pelindung wajah & hazmat mask & special term \\
\hline karantina wilayah & lockdown & special term \\
\hline kekebalan kelompok & herd immunity & special term \\
\hline kenormalan baru & new normal & special term \\
\hline pelindung wajah & face shield & special term \\
\hline penelusuran, pelacakan & tracing & general term \\
\hline penjarakan fisik & physical distancing & special term \\
\hline penyanitasi tangan & hand sanitizer & general term \\
\hline penyaringan & screening & general term \\
\hline penyintas & survivor & general term \\
\hline
\end{tabular}




\begin{tabular}{|l|l|l|}
\hline percikan & droplet & general term \\
\hline terkonfirmasi & confirmed & general term \\
\hline uji cepat & rapid test & special term \\
\hline uji usap & swab test & special term \\
\hline wabah & Outbreak & general term \\
\hline
\end{tabular}

There are 21 terms that match by absorption. The absorption method is the most common matching method [14]. The twenty-one terms are divided, 17 terms that are absorbed by spelling and pronunciation adjustments, namely antiseptic, disinfectant, epidemic, incubation, isolation, quarantine, chloroquine, cluster, contingency, corona virus, mask, mobilization, pandemic, prevalence, protocol, reactive, and specimen; and 4 terms with adjustments without spelling, but with pronunciation adjustments, namely pneumonia, respirator, ventilator, and zoonosis.

TABLE II. FORMATION OF TERMS THROUGH ABSORPTION

\begin{tabular}{|l|l|l|}
\hline \multicolumn{1}{|c|}{ Indonesian Term } & \multicolumn{1}{c|}{ Foreign Term } & Form \\
\hline Antiseptik & antiseptict & special term \\
\hline Disinfektan & disinfectant & special term \\
\hline Epidemi & epidemic & special term \\
\hline Inkubasi & incubation & special term \\
\hline Isolasi & isolation & general term \\
\hline Karantina & quarantine & special term \\
\hline Klorokuin & chloroquine & special term \\
\hline Kluster & cluster & general term \\
\hline Kontingensi & contingency & general term \\
\hline koronavirus, virus korona & corona virus & special term \\
\hline Masker & mask & general term \\
\hline Mobilisasi & mobilization & general term \\
\hline Pandemi & pandemic & general term \\
\hline Pneumonia & pneumonia & special term \\
\hline Prevalensi & prevalence & special term \\
\hline Protokol & protocol & general term \\
\hline Reaktif & reactive & general term \\
\hline Respirator & respirator & general term \\
\hline Spesimen & specimen & general term \\
\hline Ventilator & ventilator & general term \\
\hline Zoonosis & zoonosis & special term \\
\hline & &
\end{tabular}

There are 20 terms that match them through a combination of translation and absorption. However, there are two terms that actually enter into matching through absorption if no synonym is found, namely corona suspect becomes suspek korona and incubation period becomes periode inkubasi so the total number of matching terms Covid-19 through absorption is 22 .

TABLE III. FORMATION OF TERMS THROUGH COMBINED TRANSLATION AND ABSORPTION

\begin{tabular}{|l|l|l|}
\hline \multicolumn{1}{|c|}{ Indonesian Term } & \multicolumn{1}{c|}{ Foreign Term } & \multicolumn{1}{c|}{ Form } \\
\hline isolasi mandiri & self isolation & special term \\
\hline kasus impor & imported case & special term \\
\hline kasus konfirmasi & confirm case & special term \\
\hline kasus konfirmasi dengan gejala & symptomatic confirmed case & special term \\
\hline kasus konfirmasi tanpa gejala & asymptomatic confirmed case & special term \\
\hline kasus suspek & suscpect case & special term \\
\hline kontak erat & close contact & special term \\
\hline kontaminasi silang & cross contamination & special term \\
\hline masa inkubasi & incubation period & special term \\
\hline pelandaian kurva & flattening the curve & special term \\
\hline pembatasan sosial & social restriction & special term \\
\hline penjarakan media sosial & social media distancing & special term \\
\hline penjarakan sosial & social distancing & special term \\
\hline penularan lokal & local transmission & special term \\
\hline
\end{tabular}




\begin{tabular}{|l|l|l|}
\hline penyakit koronavirus & coronavirus disease (Covid-19) & special term \\
\hline swakarantina, karantina mandiri & self-quarantine & special term \\
\hline terduga korona, suspek korona & corona suspect & special term \\
\hline tes serentak & massive test & special term \\
\hline tes usap tenggorokan & throat swab test & special term \\
\hline uji strep cepat & rapid strep test & special term \\
\hline
\end{tabular}

In addition to foreign terms affected by matching, there are several terms that are affected by the process of shaping the terms through translation, but in their use, it is more popular in terms of the acronym form, namely APD (alat pelindungan diri) which is translated from hazmat suit. However, there are also foreign terms that are more popular with the acronym form, such as WFO (work from office) dan WFH (work from home) although the matching has been made by the Ministry of Education and Culture, namely KDK for kerja dari kantor (WFO) and KDR for kerja dari rumah (WFH), but in the mass media it is more popular to adapt acronyms to foreign terms or to translate them if it is in the form of Indonesian terms, namely kerja dari rumah and kerja dari kantor rather than the acronym form.

There is also the term acronym form that is raised for situations that suit the conditions in Indonesia. The emergence of new terms through acronyms gives color to the symptoms of word formation in Bahasa Indonesia [7] although initially a form of matching of foreign terms. However, these terms were formed in the context of the protocol for handling and preventing the spread of Covid19 in Indonesia specifically so that the formation of these terms came from Indonesian in the form of an acronym. The terms of the acronym form are SIKM (surat izin keluar masuk/entry and exit permit) which is in the Governor's Regulation (Pergub) Number 60 of 2020 concerning Pengendalian Kegiatan Berpergian di Provinsi DKI Jakarta dalam Upaya Pencegahan Penyebaran Covid-19 and PSBB (pembatasan sosial berskala besar/large-scale social restrictions) from Government Regulation No. 21 of 2020 concerning Pembatasan Sosial Berskala Besar dalam Rangka Percepatan Penanganan Covid-19, Minister of Health Regulation No. 9 of 2020 and variations of the terms that follow, PSSB Transisi (Transitional PSSB) and PSBB Proporsional. Covid-19 related terms also emerge from the geospatial field, namely peta risiko, zona aman, zona risiko, zona merah, zona oranye, zona kuning, and zona hijau. These terms in the geospatial field form the basis of government decision making which gave rise to the term SIKM (surat izin keluar masuk), PJJ (pembelajaran jarak jauh), PSBB transisi, dan PSBB proporsional.

In addition to government policy using the term PSBB acronym, there is also the term ODP acronym (orang dalam pemantauan), PDP (pasien dalam pengawasan), OTG (orang tanpa gejala), and KLB (kejadian luar biasa) contained in official documents of the Directorate General of Disease Prevention and Control Pedoman Pencegahan dan Pengendalian Coronavirus Disease (Covid-19) March, 2020 4th Revision [2]. The acronyms originating from Bahasa Indonesia term are a form of prioritizing Bahasa Indonesia in public spaces conducted by the government. In July 2020, the government through the Ministry of Health issued Pedoman Pencegahan dan Pengendalian Coronavirus Disease (Covid-19) March, 2020 5th Revision
[1] which replaces the term new normal or new normality (kenormalan baru) with the term acronym form, namely AKB (adaptasi kebiasaan baru/adapt to new habits) and replace the term of the ODP, PDP, OTG acronym form with kontak erat (close contact), kasus suspek (suspect case), dan kasus konfirmasi tanpa gejala (asymptomatic confirmed case) also gave rise to the terms selesai isolasi (finished isolastion), kematian (death due to Covid-19), pelaku perjalanan (travel agent), kasus probable (probable case), and discarded [15-22]. Use of term kontak erat (close contact), which was previously also separate from the use of the term acronym form ODP, PDP, and OTG narrowing the meaning into a substitute for the term of ODP. The replacement of this term is a form of linguistic creativity [23] as an illustration of the dynamics of conditions and phenomena in the midst of the Covid-19 pandemic.

However, unfortunately the appearance of the term of kasus probable (probable case) if guided by PUPI will be absorbed into probabel or in full kasus probabel and the appearance of terms discarded those who still use foreign terms make the impression of lack of prioritizing Bahasa Indonesia or the lack of involvement of language experts (Kemdikbud) in efforts to deal with the Covid-19 pandemic carried out by the Ministry of Health in the latest policy. Preferably, the Ministry of Education and Culture in this case Language and Book Development Agency helps to review terms by matching into Indonesian in accordance with applicable rules [24].

The substance of scientific material in Bahasa Indonesia as a compulsory subject is the skill to use Bahasa Indonesia as a national language and national language properly in the framework of academic writing [25]. This means that knowledge and use of official language guidelines from the products of the official state institutions responsible for language management must be conveyed and mastered to students. The basic competence of diction lecture material is students are able to choose the right diction in the correct Bahasa Indonesia framework to create written work. For example, essay papers, papers, research reports, and journal articles. The ability to choose the right diction is an absolute requirement in scientific activities [8]. One indicator of accuracy in choosing diction is when students are able to identify the formation of terms in Bahasa Indonesia. With the ability to identify this, students can determine whether the form of terms used in his work is the form of terms that exactly represent the ideas he wants to convey. Indirectly, this ability to identify also supports the ability to use standard words in Bahasa Indonesia.

The use of Covid-19 related terms as alternative lecture materials is an effort to present social contexts that are relevant to what students are listening to and experiencing so that the delivery of scientific material on diction, especially sub material of the formation of terms based on PUPI will be more effective. The application of PUPI in 
order to practice the habit of writing with the use of standard terms is in need of practice and relevant examples [26]. The context of the situation in language plays a role in the selection of texts or sentences with diction in accordance with the language situation that arises [27]. The list of terms related to Covid-19 that has been analyzed can be used as an exercise or example in the application of concepts in PUPI so that lecturers and students get a more contextual form of material content. This is consistent with Haliday and Hasan in Symasuri [28] that the text is social semiotic means that the text is a language that functions to convey the context of the situation or in short, there will never be a meaningful text without context.

\section{CONCLUSION}

The term that appears in Indonesian government policy to break the chain of the spread of Covid-19 is packaged in linguistic products, namely the term. Through these terms government policies are disseminated to the public. The dominance of English in terms related to Covid-19 proves that Covid-19 is a global pandemic affecting the world. This is also evidence that the Indonesian government in making and deciding policies always considers information released by WHO as the World Health Organization which naturally uses English as its language of instruction. The results of data collection in this study there are 80 terms used in mass communication media both from official news issued by the government, such as from the website covid19.go.id (the official website of the Covid-19 Response Acceleration Task Force in Indonesia) or from general news released by mass media sites with legal status, such as kompas.com and republika.co.id.

The results of the analysis of the formation of the terms there are 15 terms in English that matching by translation, 21 terms with absorption, but there are two terms that if no synonyms are found, enter the formation of terms through absorption so that the number of terms related to Covid-19 through absorption can be 22 terms, 20 terms with a combination of translation and absorption, 10 terms in acronym form, 9 special terms used in government policy from a geospatial perspective, and 5 other terms that appear in the latest rules to replace the terms that already existed in previous policies. The replacement of this term is a form of linguistic creativity as a picture of the dynamics of conditions in the middle of the Covid-19 pandemic. The list of terms related to Covid-19 that has been analyzed can be used as an exercise or example in the application of concepts in PUPI as learning sub material diction in Bahasa Indonesia general subjects. Utilization of Covid-19 related terms as alternative lecture material in learning diction in Indonesian Language so that lecturers and students get more contextual and relevant material content with the results of student simulations and experiences so that the delivery of scientific material on the diction is expected to be more effective.

\section{REFERENCES}

[1] (2020). Pedoman Pencegahan dan Pengendalian Coronovirus Disease (Covid-19) Revisi Ke-5. Available: https://covid19.kemkes.go.id/protokolcovid-19/kmk-no-hk-01-07-menkes-413-2020-ttgpedoman-pencegahan-dan-pengendalian-covid19\#.XxaLqygzbIU

[2] (2020). Pedoman Pencegahan dan Pengendalian Coronavirus Disease (Covid-19) Revisi Ke-4. Available:

https://infeksiemerging.kemkes.go.id/download/REV04_Pedoman_P2_COVID-

19_27_Maret2020_TTD1.pdf

[3] Kemenkes. (2020). Situasi Terkini Perkembangan Coronavirus Disease (Covid-19) 18 Juli 2020. Available: https://covid19.kemkes.go.id/situasiinfeksi-emerging/info-corona-virus/situasi-terkiniperkembangan-coronavirus-disease-covid-19-18-juli2020/

[4] M. T. Qodratillah, Seri Penyuluhan Bahasa Indonesia: Tata Istilah. Jakarta: Pusat Pembinaan Badan Pengembangan dan Pembinaan Bahasa Kementerian Pendidikan dan Kebudayaan, 2016.

[5] (2007). Pedoman Umum Pembentukan Istilah. Available:

http://badanbahasa.kemdikbud.go.id/lamanbahasa/sites /default/files/Pedoman_Umum\%20Pembentukan_Istila h PBN 0.pdf

[6] H. Kridalaksana, in Kamus Lingustik, ed. Jakarta: Gramedia Pustaka Utama, 2001.

[7] M. Zaim, "Pergeseran Sistem Pembentukan Kata Bahasa Indonesia: Kajian Akronim, Blending, dan Kliping," Masyarakat Lingustik Indonesia, vol. 33, no. 2, pp. 173-192, 2015.

[8] R. Tarigan, "Peranan Bahasa Indonesia dalam Penulisan Karya Ilmiah," Jurnal Ilmiah Integritas, vol. 5 , no. 1,2019

[9] G. J. E. o. J. Gusnayetti, "Pentingnya Penggunaan Bahasa Indonesia di Perguruan Tinggi," vol. 2, no. 3, pp. 15-22, 2020.

[10] "Kamus Besar Bahasa Indonesia," ed: Badan Pengembangan dan Pembinaan Bahasa Kementerian Pendidikan dan Kebudayaan, 2016.

[11] J. R. Raco, Metode Penelitian Kualitatif Jenis, Karakteristik, dan Keunggulannya. Jakarta: Grasindo 2010

[12] A. J. J. T. Wismanto, "Interdependensi antara Bahasa Indonesia dengan Iptek sebagai Penghela Pembentukan Istilah Melalui Media Bahasa," vol. 3, no. 1, p. 502, 2017.

[13] A. Putri Ashilah, "Kosakata Serapan Bahasa Inggris dalam KBBI V," Jurnal Sapala, vol. 7, no. 1, 2020.

[14] S. S. Budiwaty, "Strategi Pembentukan Istilah Asing dalam Penyusunan Glosarium Terminologi Penerjemahan Inggris-Indonesia," UG Journal, vol. 8 , no. 1,2014

[15] Caksono. (2020). 4 Istilah Baru Definisi Operasional Penanganan Covid-19. Available: https://mediaindonesia.com/read/detail/329099-4istilah-baru-definisi-operasional-penanganan-covid-19

[16] P. A. M. Fajrin. (2020). Daftar 6 Istilah Baru Terkait Covid-19 dan Penjelasannya. Available: https://katadata.co.id/pingitfajrin/berita/5f0e8ddf58674 /daftar-6-istilah-baru-terkait-covid-19-danpenjelasannya

[17] N. Febrianto. (2020). Penjelasan 7 Istilah Baru dari Terawan Seputar Covid-19. Available: https://www.tagar.id/penjelasan-7-istilah-baru-dariterawan-seputar-covid19

[18] F. Mursid. (2020). Kemenkes Ganti Istilah ODP, PDP dan OTG dengan Suspek. Available: 
https://republika.co.id/berita/qdgpmt396/kemenkesganti-istilah-odp-pdp-dan-otg-dengan-suspek

[19] D. E. Nugraheny. (2020). Perubahan Istilah OTG, ODP, PDP, dan Penjelasan Pemerintah. Available: https://nasional.kompas.com/read/2020/07/15/0753178 1/perubahan-istilah-otg-odp-pdp-dan-penjelasanpemerintah?page $=$ all

[20] D. Nurita. (2020). Peraturan Baru, Terawan Hapus Istilah PDP, ODP, dan OTG Covid-19. Available: https://nasional.tempo.co/read/1364898/peraturanbaru-terawan-hapus-istilah-pdp-odp-dan-otg-covid-19

[21] A. E. Prawira. (2020). 4 Istilah Baru Terkait Covid-19. Available:

https://www.liputan6.com/bola/read/4304599/4-istilahbaru-terkait-covid-19

[22] D. V. Putsanra. (2020). Daftar Istilah Baru COVID-19 Pengganti PDP, ODP, OTG, dan Positif. Available: https://tirto.id/fQ7X

[23] S. Nafisah and I. J. D. Budiarso, "Pembentukan Kata pada Istilah Khas di Instagram dengan Unsur Bahasa Inggris," vol. 12, no. 01, pp. 75-91, 2020

[24] N. Nazriani and A. J. S. P. J. I. U. M. B. Arsad, "Kesalahan Penggunaan Bahasa Indonesia dalam Ruang Publik (Media Luar Ruang) di Kota Baubau," vol. 6 , no. 1, pp. 8-17, 2020.

[25] [R. Hidayat, K. Khotimah, and A. J. J. I. T. Saputra, "Mata Kuliah Wajib Umum Bahasa Indonesia di Perguruan Tinggi: Sebuah Tawaran Model Pembelajaran," vol. 4, no. 1, pp. 31-35, 2019.

[26] M. J. S. L. Erlinawati and J. I. Indonesia, "Implementasi Pembakuan Peristilahan Perkomputeran Dalam Bahasa Indonesia Untuk Mahasiswa SI 18A4 FIKOM Universitas Duta Bangsa Surakarta," vol. 5, no. 2, pp. 92-99, 2020.

[27] D. P. Setiyadi, "Diksi yang Mengandung Berbagai Nilai Rasa sebagai Materi Ajar Bahasa Indonesia untuk Membentuk Perilaku Santun dalam Berbahasa," in PROCEEDING, 2014.

[28] A. S. Syamsuri, "Bahasa Indonesia sebagai Penghela Ilmu Pengetahuan dan Wahana Ipteks: Pembentukan Istilah Sebagai Salah Satu Usaha Mewujudkannya " in Kongres Bahasa X, Jakarta, 2013, no. Penguatan Bahasa Indonesia di Dunia Internasional: Badan Pengembangan dan Pembinaan Bahasa Kementerian Pendidikan dan Kebudayaan. 